\title{
The Effect of Board and Ownership Structure on the Efficiency of Banks in Tunisia: The Stochastic Frontier Approach
}

\author{
Salima Taktak ${ }^{1} \&$ Mohamed Triki ${ }^{1}$ \\ ${ }^{1}$ Unity of Research Governance, Sfax University, Sfax, Tunisia \\ Correspondence: Salima Taktak, Unity of Research Governance, Sfax University, Sfax, Tunisia. Tel: \\ 216-22-184-322. E-mail: Salima.taktak@yahoo.fr
}

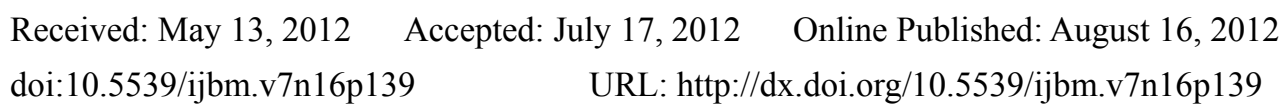

\begin{abstract}
The corporate governance problem is likely to be worse in banks due to their attributes (greater opaqueness than other industries, greater government regulation...) that weaken many traditional governance mechanisms. The purpose of this research is to explore the governance characteristics of the Tunisian listed banks and to detect the impact of the internal governance mechanisms on their efficiency during the period 2002-2009.

Our findings indicate that the structure and the size of the board of directors and the ownership structures present divergent effects on the banks efficiency. Then, empirical results show that Tunisian listed banks display a middle efficiency level of $81.60 \%$ during the period 2002-2006. The deterioration of the efficiency level is owed to big public bank; in fact, private banks are more efficient than the public ones.
\end{abstract}

Keywords: corporate governance, bank, board of director, ownership structures, efficiency, stochastic frontier approach

\section{Introduction}

The emergence of the idea of "corporate governance" is generally attributed to the debate opened by Berle and Means (Note 1), which followed the 1929 crisis. For these authors, the problem of governance is born of the dismemberment of the property function in a control function and an adjudicative function. This evolution occurred in corporate America in the early twentieth century.

Financial institutions, mainly banks, are particularly concerned with corporate governance. In fact, banks are characterized by agency problems and distinct accents from other unregulated firms. These agency problems are mainly caused by the information asymmetry existing between all players in the banking sector. Opacity and regulation are at the heart of corporate governance.

Most studies of governance have ignored the problems of governance of banks in emerging countries (Caprio et al., 2007). However, this topic is important for several reasons. On the one hand, banks occupy a dominant role in the economies of these countries. They are a major component of any national economy. On the other hand, the change of the international response to globalization, liberalization, deregulation of financial systems, the adoption of new banking technologies affect the operation of banks.

In Tunisia, despite structural changes in the financial system that have strengthened the role of financial market since the early nineties, bank intermediation is still the major mode of financing the economy. The group of Tunisian banks is the most important agent in the Tunisian financial system.

Given all these considerations, it is interesting to conduct a study focused on the Tunisian banking sector. Our work is based on research relating to corporate governance and proposing several control mechanisms to mitigate agency conflicts within financial institutions and improve their performance (Laeven and Levine, 2009). Specifically, our goal is to identify the impact of internal governance on the performance of Tunisian banks.

Our article is organized as follows. First, we present the theoretical framework and research hypotheses. Then we deal with the methodological aspects. Analysis and discussion of our results is the subject of the next sextion. The conclusion summarizes the main results of this research, as well as points out the limitations of the study.

\section{Literature Review: The Governance of Banks}

The bank is not a business like any business. Certainly, it has a legal status, an organizational structure, a 
management system, products and strategies. But it lends money; it collects savings from the public and manages means of payment. Banks occupy a very important role in the economies of countries. They are a major component of any national economy.

As a result of this importance, governments of countries ensure that the activities of banks are regulated. In most countries, banks are responsible for abiding by both state and national regulatory rules. Both are exercised in the form of bank supervision.

Central banks are considered the highest authority that exercises this control. Banking supervision that is completely internal is insufficient. For this reason, a system of good governance should be applied at banks and financial institutions.

To address the question of how relevant this is to "government banks", we must take into account the specificity of these institutions compared to other companies.

\subsection{The Specifics of Bank Governance}

\subsubsection{The Opaqueness}

The empirical evidence on banking institutions are unanimous on the fact that they are considerably more opaque than firms operating in unregulated industries. The opacity of banks means the difficulty of determining their current performance. Investors have less information from management concerning the fate of their funds (Caprio and Levine, 2003). Although information asymmetry is a phenomenon present in all types of businesses, it is pronounced in the case of banks (Polo, 2007).

\subsubsection{Regulations}

Prudent regulation of banks has become a key concern of the authorities of developed and emerging countries, and is justified by the financial system and safeguarding the public interest. Indeed, effective control of banks is essential given their role in payment transactions and credit and the spread of bankruptcy of one bank to all other banks, even those that are successful (Delorme, 2002) (Note 2). However, the presence of regulatory changes the agency relationship between shareholders and managers, and by introducing a third party who is the regulator, creating greater information asymmetry and thwarting the effectiveness mechanisms of governance (Macey and O'Hara, 2003). Therefore, these arguments imply that governance problems of banks are widely different from those of other unregulated businesses.

\subsection{Mechanisms of Bank Governance}

The system of governance of banks is strongly influenced by the specificities of the banking sector. Indeed, it is more complex with multiple partners' interests. This system of governance mechanisms can be divided into external and internal mechanisms.

\subsubsection{External Mechanisms}

The main external governance mechanisms are the banking market for goods and services, the market for takeovers and the labor market. In banking, the efficiency of these markets is weakened by opacity and regulation.

Indeed, competition in the market for goods and services is very low at banks, given that leaders set the limitations on access to necessary information (Laeven and Levine, 2009). In addition, competition between banks is limited by the shareholders of the state that holds substantial bank capital and shareholding families pronounced that prevents the entry of new competitors (Caprio and Levine, 2002) (Note 3).

Similarly, the takeover does not end if the necessary information on the bank and its environment are not available. They are very rare in the case of the banking sector in emerging markets, and even in industrialized countries, except the U.S. (Prowse, 1997).

The disciplinary role exercised by the labor market is also limited by the weak signs sent by the banks on the quality of managers. Thus, the poor performance of banks can be explained by several external factors such as economic conditions, but it is difficult to see the responsibility of its leaders.

The system of governance of banks is characterized by external mechanisms to controversial effects, discipline exerted by the markets, limited or ineffective (Adams and Mehran, 2005), which give the internal mechanisms of vital importance in the governance of banks and the preservation of their performance.

\subsubsection{Internal Mechanisms}

For the banking sector, and firms in general, corporate governance is characterized by internal mechanisms 
aimed to influence and monitor the behavior of the organization and its leadership. These mechanisms are distinguished, in particular, by the role played by the disciplinary board and ownership structure.

The board is an important player in the process of bank corporate governance; indeed, they are responsible for the effectiveness of governance mechanisms and specific internal control systems. The Board's primary role is defining objectives and strategies of the bank, control and discipline of officers, evaluating the performance of the bank, development of plan for executive compensation, managing communication systems and disclosure of information regarding all bank operations.

The ability of the Board to fulfill its role depends mainly on its composition and size (Nam, 2004).

In the banking system of governance, the ownership structure is also of great importance. Its effectiveness depends on the nature of shareholders, objectives and scope of their disciplinary and executive decision making powers.

Thus, individual shareholders should focus on the team management of banks more than working effectively, as opposed to market discipline. They are able to limit the discretionary latitude of the management team. They play an active role in aligning the interests of executives with their interests. They are usually represented on the board and contribute to the development strategies of the bank and control of leaders. This concerns more major shareholders of any nature whatsoever of local and foreign private institutions, public institutions and state.

\subsection{Some thoughts on the Relationship between Internal Governance Mechanisms and Performance of Banks}

The empirical evidence, considering the relationship between internal governance mechanisms, found that the board of directors and ownership structure and performance are very limited for banks in emerging countries (Arun and Turner, 2004). Banks have long been considered the main creditors, since they play an important role in the governance of other companies, but little is known about their governance systems (Caprio et al., 2007).

In what follows, we quote the main studies that address the relationship between the internal mechanisms of governance and performance, and explain the results we deduce hypotheses to be tested empirically.

\subsubsection{Impact of Ownership Structure on the Performance of Banks}

Empirical studies on the impact of ownership structure on performance of banks and firms, in general, give rise to contradictory results. The two aspects of ownership (i.e. ownership concentration and nature of the shareholders) may be positively or negatively correlated with bank performance.

The effect of ownership concentration on the performance of the bank is theoretically and empirically ambiguous. In fact, many studies have found a positive influence of the presence of shareholders on performance. While other studies have concluded that there is no relationship between ownership concentration and performance.

Spong et al. (1996), suggest that the most important factor affecting performance positively is banking capital concentration. This was done by examining 143 U.S. banks from 1990 to 1994. Similarly, Caprio et al. (2007) showed that ownership concentration has a positive effect on the performance of banks after studying 244 banks from 44 countries. Indeed, these authors find that banks, internationally, are generally characterized by a concentrated ownership structure and the majority shareholder of the bank is either a family or the state.

However, some authors such as Demestz and Villalonga (2001) suggest that there is no significant difference in performance between the diffuse capital firms and those whose capital is held by a shareholder. In the same frame of reasoning, Pinteris (2002) reveals a negative, but not statistically significant, correlation between the concentration of ownership and performance of banks, following his research focusing on the banking sector in Argentina. In fact, investors perceive unfavorable banks with concentrated ownership structure, given that shareholders can expropriate resources and enjoy the benefits of control.

From the overlap of previous studies, we formulate our first research hypothesis:

\section{H1. The concentration of capital has a positive influence on the performance of banks.}

The importance of control exercised by institutional investors and its impact on company performance has been studied by more than a researcher. This impact is, however, ambiguous nature.

Empirical studies by Mikkelson and Rubach (1985) (Note 4) demonstrate the existence of positive abnormal returns associated with the announced acquisition of an equal or greater than $5 \%$ of the shares of a given company by another company. Also, McConnel and Servaes (1990), in turn, found a positive relationship between institutional investors and shareholders of the company's performance measured by Tobin's Q.

In the same frame of reasoning, Berger and Bonaccorsi di Patti (2003), after studying 695 U.S. commercial banks spanning the period 1990-1995, find that large institutional investors produce control effects that reduce 
the cost of agency and increase performance.

However, Barclay and Holderness (1991) (Note 5), Shleifer and Vishny (1997) argue that the intensity of the relationship between the presence of institutional investors and performance depends on the behavior of these investors, and that they have no effect on efficiency of the company when they are actively involved in governing the organization.

Therefore, we formulate our second research hypothesis:

H2. The presence of institutional investors has a positive influence on the performance of banks.

Several empirical studies have examined the effect of foreign ownership on the performance of banks and mainly in developing countries.

Leightner and Lovell (1998) (Note 6) argue that openness to foreign capital banks in emerging countries improve their performance by providing access to technology and especially the best governance practices. Also, Claessens et al. (2001), Pinteris (2002) reported that in several developing countries (such as Egypt, Indonesia, Argentina and Venezuela), foreign banks record net profit margins and higher interest than those recorded by local banks. In the same frame of reasoning, empirical studies conducted by Claessens and Laeven (2004), Bonaccorsi di Patti and Hardy (2005), found that the introduction of foreign ownership in banks and reducing legal restrictions on this form of property, mainly in developing countries, generates greater competitiveness for local banking systems.

Weill (2006) compares the technical efficiency of banks in domestic ownership and foreign ownership in Poland and the Czech Republic. The estimated efficiency scores are performed by means of data envelopment analysis (DEA). He then shows that banks with foreign ownership have greater technical efficiency than domestic banks.

Lensink et al. (2006) (Note 7) found that the presence of foreigners in the ownership structure is negatively related to bank efficiency. The magnitude of this negative impact is dependent on regulation in the transition economies.

From the overlap of previous studies, we formulate our third research hypothesis:

H3. The presence of foreign investors has a positive influence on the performance of banks.

The shareholding of the state in banks is a common theme in all countries. In a study analyzing the ownership structure of banks internationally, La Porta et al. (2002) show that the shareholding of the state is higher in countries with weak protection of shareholder rights, increased government intervention in the economy and financial system underdeveloped.

Several empirical studies have examined the effect of state ownership on bank performance. Barth et al. (2000) (Note 8) and Lang and so (2002) find that economic performance decreases with the state participation in bank capital.

In this context, Berger et al. (2009), find that the effects of state ownership on bank performance are negative and that banks that are stymied by the State are performing more poorly than those of private banks owned by local or foreign shareholders.

We use this effect to create the following hypothesis:

H4. State presence has a negative influence on the performance of banks.

\subsubsection{Impact of the Board on the Performance of Banks}

Empirical studies examining the effect of the Board on the performance of banks and firms give rise to contradictory results. Board size, the presence of each type of director (independent and institutional), the chairman and CEO, may be positively or negatively correlated with bank performance. In what follows, we quote the main studies, explain the results and deduce hypotheses to be tested empirically.

Most research in the banking sector shows that boards with a reduced number of directors have control their operations more effectively as compared with boards that have large number of shareholders with different interests (Lipton and Lorsch, 1992).

Adams and Mehran $(2003,2005)$ find that boards of directors of banks are larger. Adams and Mehran (2005) studied the relationship between board size and performance of 35 banks and bank holding companies in the United States from 1986 to 1999 . They conclude that banks, having a larger council, are not less efficient than their peers in terms of performance measured by Tobin's Q.

Therefore, we expect that: 


\section{H5. A large board improves the performance of banks.}

Institutional investors play an active role in the governance of banks. These individuals represent shareholders and are influential partners for the bank through their considerable financial resources enabling them to become very active investors (Whidbee, 1997) (Note 9).

Institutional investors will tend to sit on the board for active control of the activities of the leader (Agrawal and Knoeber, 1996). Indeed, their presence on the board empowers them to vote in major decisions on recruitment, remuneration and dismissal of officers and dividend policy. Also, they may have the information of the bank and ask for explanations concerning the operations of the bank. Thus, the presence of institutional administrators can influence the disciplinary powers of the board and improve the performance of the bank. This brings us to provide that:

\section{H6. The presence of institutional directors on the board has a positive influence on the performance of banks.}

The influence of the presence of independent directors on the board of directors on performance was the issue of several researchers who have adopted very different approaches to highlight the significance of this influence. The majority of studies concluded that there is a positive influence, to the extent that the independent will have a more neutral view on the company.

The banking literature states that the independent directors must ensure that banks apply their own regulations and activities, and that those leaders do not have the power to make discretionary decisions that are harmful to shareholder wealth (Nam, 2004).

However, several authors state that outside directors are not able to understand the complexity of business operations and they are incompetent officers in the exercise of control and surveillance. In addition, they may have different interests, which can create conflicts of interest between the board and management team (Prowse, 1997; Linck et al., 2006 (Note 10)).

In addition, Griffith et al. (2002) find no relationship between performance and board composition, thus confirming the results of Pi and Timme (1993). Similarly, Adams and Mehran (2005) reveal that the percentage of outside directors has no effect on the market performance of banks and accounting.

We then set the following hypothesis:

H7. The presence of independent directors on the board has no influence on the performance of banks.

The literature on the problem called 'duality', or accumulated positions of CEO and Chairman of the Board, present separate opinions.

Some authors argue this should be a combined position for reasons of efficiency of the unit of management and others denounced this for abuse of power by the executive.

Regarding the banking sector, few studies have addressed the effect of duality on performance of banks. Pi and Timme (1993) find that efficiency and performance of banks' assets are lower under duality. At the end of their investigation on large U.S. commercial banks during the years 1988-1990, conflicts with the duality of principal / agent were found to be exacerbated because of the consolidation process control and decision. In addition, Gary and Gleason (1999) suggest that duality can increase the power of the executive on the board of the bank significantly.

However, proponents of duality claim that this practice allows an increased knowledge of the business environment and a better skill on the part of Chairman of the Board, and subsequently improve the performance of the company (Marsinko and Sridharan, 1997(Note 11)).

From the overlap of previous studies, we make our last research hypothesis:

\section{H8. Duality has a negative impact on the performance of banks.}

\section{Methodology}

Our study examined a sample of 10 banks (Note 12) listed on the Tunisian Stock Exchange, Securities Tunis (Tunis Stock Exchange) (Note 13).

Based on this sample, we collect financial and accounting information from financial statements and market data published by the Financial Market Council and the Professional Association of Banks in Tunisia over a period of five years from 2002 until 2009.

Our empirical analysis focuses on measuring the efficiency of Tunisian banks and explaining the level of efficiency in these banks through the internal mechanisms of governance. 
The parametric method of stochastic frontier is adopted in our study because it allows us to isolate the purely random error term that reflects the inefficiency (measured by the governance variables) and should, therefore, lead to a more efficiency in Tunisian banks.

In our methodological approach, we adopt the intermediation (Note 14) approach. In fact, this technique is most appropriate given the importance of interbank activity and the weight of interest costs (Clowell and Davis, 1992) (Note 15). Tunisian banks use the funds at their disposal to rely primarily on loans. It follows that the liability of Tunisian banks tends to be regarded as an input rather than output.

In the case of a stochastic frontier we assume that technology is specified. Therefore we will use a cost function.

Consider the Cobb-Douglas cost function (in log form) following the stochastic frontier model for panel data:

$$
L n C T_{i t}=\alpha_{0}+\alpha_{1} \operatorname{Ln}\left(C R C_{1 i t}\right)+\alpha_{2} \operatorname{Ln}\left(P F T_{2 i t}\right)+\alpha_{3} \operatorname{Ln}\left(C E B F_{3 i t}\right)+\alpha_{4} \operatorname{Ln}\left(P L_{i t}\right)+\alpha_{5} \operatorname{Ln}\left(P K_{i t}\right)+\alpha_{6} \operatorname{Ln}\left(P F_{i t}\right)+v_{i}+u_{i}
$$

Where:

CT: The total cost of bank $\mathrm{i}(\mathrm{i}=1 \ldots 10$ : The Tunisian banking population used in our study) at time $\mathrm{t}(\mathrm{t}=1 \ldots 8$ : Our study period 2002-2009),

PL: The price of labor,

PK: The price of physical capital,

PF: The price of financial capital,

CRC: The customer loans,

PFT: The securities portfolio,

CEBF: Claims on banks and financial institutions,

vi: The terms of random errors, distributed independently according to the normal distribution $\mathrm{N}\left(0, \mathrm{v}^{2}\right)$,

ui: Terms and measuring inefficiencies that are positively identified with a semi normal distribution $N\left(\mathrm{~m}_{\mathrm{it}}, \mathrm{u}^{2}\right)$.

We aim not only estimate the efficient cost frontier, but also to identify the determinants of the efficiency score assigned to each of the banks in our sample. To do this, and to avoid the pitfalls of a two-step approach, we implement the one-step approach recommended by Battese and Coelli (1995). In this model, one disassociates technical inefficiency as s deterministic component, represented by a set of governance variables supposed to influence the efficiency of the bank, a random part associated with the unobservable factors. Thus, the distribution of the random term ui on the extent of inefficiency is that of a truncated normal distribution with variance $\mathrm{u}^{2}$ and hope set defined by:

$$
m_{i t}=\delta_{0}+\delta_{1} \text { PMAJ }+\delta_{2} \text { PINS }+\delta_{3} \text { PETR }+\delta_{4} E T A T+\delta_{5} T C A+\delta_{6} A I N S+\delta_{7} A I N D+\delta_{8} D U A L+\delta_{9} L T A
$$

Where:

PMAJ: Presence of shareholders

PINS: Percentage of capital held by institutional investors

PETR: Percentage of capital held by foreign investors

ETAT: Percentage of capital held by the STATE

TCA: Size of the Board

AINS: Percentage of Independent Directors

AIND: Percentage of Institutional Administrators

DUAL: Separation of CEO and Chairman of the Board

LTA: Store Size (natural logarithm of book value of total assets)

\section{Empirical Results and Interpretation}

In what follows, we present the estimated parameters of the cost function frontier and inefficiency expectancy. Then, we interpret the factors explaining efficiency. Finally, we determine efficiency scores for the ten banks in our sample, during the period of 2002-2009.

The coefficients of the frontier cost function (a) and expectancy inefficiency (2) are estimated by maximum likelihood using the software "Frontier 4.1" (Coelli et al., 1998) (Note 16).

The program provides maximum likelihood estimators of parameters of equations (1) and (2), and evaluates the 
technical efficiency score for each observation.

In our work the main results concerning the boundary cost function are:

- The parameter $\alpha 1$ is positive and statistically significant, in fact, the output CRC (customer loans) positively influences the total cost.

- For cons, $\alpha_{2}$ and $\alpha_{3}$ parameters are statistically insignificant, that is to say, the outputs PFT (Portfolio Securities) and CEBF (the Claims on banks and financial institutions), are not significant, their influences on CT (Total Cost) will be considered void.

- The parameters $\alpha 4, \alpha 5$ and $\alpha 6$ are the prices of three inputs (PL, PK and PF). All these coefficients are positive and statistically significant.

\subsection{The Factors Explaining Efficiency}

- The results show that the presence of a majority shareholder has a positive and significant impact on the efficiency of the Tunisian banks listed. This corroborates results from Caprio et al. (2006) which indicate that the concentration of ownership is an effective governance mechanism to exercise control over the leaders and improve the performance of banks.

- The presence of institutional investors has a negative effect on the efficiency of banks in our sample. Indeed, these institutional investors can influence bank performance positively when they are actively involved in the government of the bank (Barclay and Holderness, 1991) (Note 17).

- The presence of foreign investors has a negative and insignificant impact on the efficiency of Tunisian banks listed, thus supporting the results of several studies such as Lang and So (2002), Berger et al. (2003). These authors do not consider the shareholding of foreign investors as a means to improve the performance of banks in emerging countries. Similarly, Lensink et al. (2006) (Note 18) found that the presence of foreigners in the ownership structure is negatively related to bank efficiency. They indicate that the extent of this negative impact depends on the regulations in countries in transition.

- The percentage of capital going to the State is negatively and significantly correlated with the efficiency of banks confirming the results of Lang and So (2002), Barth et al. (2005), Berger et al. (2009). In fact, these authors found that the effects of state ownership on bank performance are negative. Indeed, banks that managed by the State are performing lower than those of private banks owned by local or foreign investors. The state-owned banks would suffer any disciplinary effect from the financial market. Thereby they encourage their leaders to follow their own interests at the expense of the interests of their institutions. Managers of private banks suffer when there is more pressure from their environment and a more intense disciplinary effect of financial market (Lang and So, 2002).

- The size of the board of directors has a negative and statistically significant impact on the efficiency of the Tunisian banks listed. These results corroborate the work of Lipton and Lorsch (1992); Montandrau (2006) (Note 19). A high number of directors on the board increases the expertise and increases the potential conflicts. This presents a greater potential for disagreement and lack of coordination in management decisions. Thus, the Board having a reduced number of directors is more effective in carrying out its functions and in monitoring officers as the board.

- The presence of institutional directors on the board of directors is positively correlated with the efficiency of Tunisian banks listed but is not statistically significant. Indeed, the nature of directors does not affect banks efficiency. Thus, we can estimate that the presence of institutional directors does not improve the efficiency of the bank.

- The percentage of independent directors does not have a significant impact on the efficiency of Tunisian banks. This result was proved by several authors such as Klein (1998) (Note 20), Adams and Mehran (2003, 2005), which stipulate that independent directors are not able to understand the complexity of bank activities, resolve conflicts and fulfill their primary role to learn the discipline of officers.

- Duality has a positive and statistically significant. Indeed, combining the functions of chairman and CEO allows a better knowledge of the activities and environment of the bank. The dual structure improves the competence and commitment of leaders to lead to greater efficiency of banks. These would be motivated to develop a good reputation in the labor market. Our result is consistent with those of Sridharan and Marsinko (1997) (Note 21), Godard and Schatt (2000) (Note 22). Thus, for Tunisian banks, the practice of duality is not necessarily harmful to shareholders. 


\subsection{Efficiency Scores Estimated}

The efficiency analysis of Tunisian banks listed showed that the sector, as a whole, showed a significant change over time in average efficiency levels, reaching the highest score at the end of the study period $(87.64 \%)$. This significant improvement in the efficiency of the Tunisian banking sector is mainly due to restructuring actions and financial reforms undertaken by the monetary authorities in Tunisia, which has resulted in a positive impact of increased competition on the efficiency.

Tunisian banks all display average efficiencies between $62.35 \%$ (BNA) and 98.15\% (ATB), to give an industry average of around $81.6 \%$.

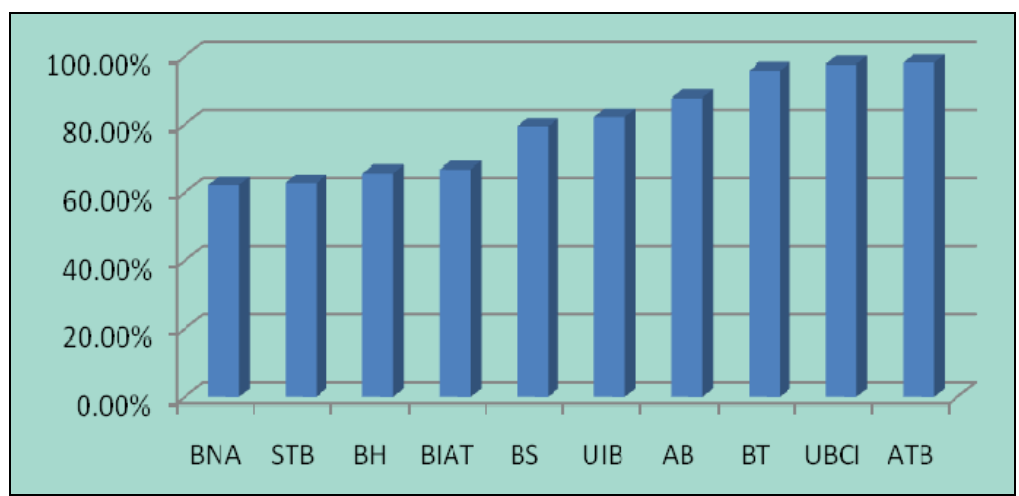

Figure 1. Average efficiency Tunisian banks (2002-2009)

At the individual level, we find that the banks of small and medium size (Note 23) in our sample, such as UBCI, $\mathrm{AB}, \mathrm{ATB}, \mathrm{BT}$, show average efficiencies better than those seen by banks of large sizes, such as BNA, STB, BIAT and BH. Indeed, over the study period, banks that have received the highest efficiency scores are ATB (0.981) and UBCI (0.977), followed by BT (.959). Such results imply that with the same resources used, these banks are able to increase their efficiency by $1.9 \%, 2.3 \%$ and $4.1 \%$ respectively while maintaining the same level of activity. At the bottom of the ranking are the largest banks in Tunisia. STB and BNA display the lowest average efficiencies. Indeed, the BNA uses only efficiently $62.35 \%$ of its resources.

This disparity, in terms of efficiency, between banks, may be due to problems caused by non-performing loans. Indeed the major banks which are generally characterized by a significant proportion of non-performing loans are less efficient than banks in smaller sizes that are characterized by a low percentage of non-performing loans.

Differences in levels of efficiencies between public and private banks remain relatively large. Thus, the results show that the most efficient banks are private banks (this confirms our results concerning the negative effect of state ownership, as an explanatory factor in the efficiency and performance of Tunisian banks). Depending on the level of efficiency, the first four banks are: ATB, UBCI, BT and AB and the lats are: EPS, STB and BH are owned banks.

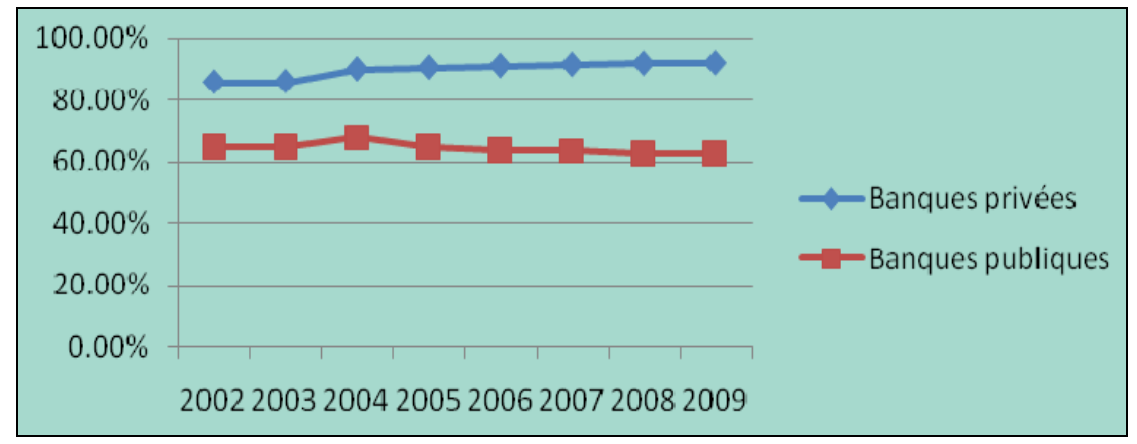

Figure 2. Scores of efficiency depending on the type of bank (public or private) 
The efficiency for private banks varies between $85.7 \%$ and $91.8 \%$, while the rate varies between $65 \%$ and $62.7 \%$ for public banks (with a slight improvement from $68 \%$ in 2004). So we can say that the deterioration in the level of efficiency of Tunisian banks is mainly due to failures of state banks. These banks may be subject to social pressures. They try to absorb the deficits in other sectors.

\section{Conclusion}

The aim of our study was to determine the incidence of internal corporate governance on efficiency. We propose an estimate of the distance to the efficient frontier of a sample of ten Tunisian banks, during the period of 2002-2009. This estimate is based on a stochastic frontier model. We also relate these efficiency scores and the internal governance of banks.

The stochastic frontier approach was used to assess the efficiency of Tunisian banks, while identifying factors explaining the level of efficiency, using the model of Battese and Coelli (1995), in one step.

Our empirical findings show that the impact of controls on the efficiency of Tunisian banks shows divergent results compared to the theoretical and empirical literature. Allowing us to confirm that the governance models adopted in banks mainly depend on the characteristics of the banking systems of each country and that optimal governance differs across industries (Gertner and Kaplan (1996) (Note 24)).

The empirical results of our research show that the improved level of efficiency of Tunisian banks is not about size, since an increase in size has a negative and statistically insignificant effect on efficiency.

As for the evolution of efficiency scores, results on panel data suggest that banks in our sample, whether small, medium or large size, have lower levels of efficiency $(81.60 \%)$. Thus, if banks use the inputs available in an efficient manner, they can reduce production costs by about $18.40 \%$ while keeping the same level of production, which shows that banks have not come to maximize their outputs given the available inputs (technical efficiency). Similarly, they use inputs in proportions given incorrect costs on the market (allocative efficiency in inputs).

The analysis of efficiency scores shows that banks in small and medium sizes in our sample, show average efficiencies, generally higher than those of large banks. Moreover, improvement of efficiency scores is relatively large in public banks, when compared with private banks. We can, therefore, say that the deteriorating level of efficiency of Tunisian banks is mainly due to failures of large state banks, to the extent that the level of inefficiency comes to $37.3 \%$ in 2009 .

Like any research, this study has some limitations that should be noted. The first is the relatively small size of our sample. The second limitation concerns the small number of factors used from which to explain the level of efficiency in banking.

Nevertheless, this work can be considered a starting point for further research. Specifically, two main research perspectives can be outlined.

The first is to add other governance variables (executive compensation), macroeconomic variables and structural variables in the banking market inefficiency term, given the importance of these variables in explaining level of bank efficiency.

One could also conduct a comparison with what is practiced in other countries, particularly emerging countries.

\section{References}

Adams R., \& Mehran H. (2003). Is corporate governance different for Bank Holding Companies?, Economic Policy Review, 9(1), 123-142.

Adams R., \& Mehran H. (2005). Corporate Performance, Board Structure and its Determinants in the Banking Industry. Cahier de recherche de la Banque fédérale de New York, 1-42.

Agrawal A., \& Knoeber C. (1996). Firm performance and mechanisms to control agency problems between managers and shareholders. Journal of Financial and Quantitative Analysis, 31(3), 377-397. http://dx.doi.org/10.2307/2331397

Arun T., \& Turner J. (2004). Corporate Governance of Banks in Developing Economies: Concepts and Issues. Corporate Governance: An International Review, 12(3), 371-377. http://dx.doi.org/10.1111/j.1467-8683.2004.00378.x

Barth J., Caprio G., \& Levine R. (2005). Bank Regulation and Supervision: What Works Best. Cahier de 
recherche de l'Université de Minnesota, World Bank Policy Research Working Paper no. 2725.

Battese G. E., \& Coelli, T. J. (1995). A Model for Technical Inefficiency Effects in a Stochastic Frontier Production Function for Panel Data. Empirical Economics, 20, 325-332. http://dx.doi.org/10.1007/BF01205442

Berger A. N., \& Di Patti E. B. (2006). Capital structure and firm performance: a new approach to testing agency theory and an application to the banking industry. Journal of Banking and Finance, 30, 1065-1102. http://dx.doi.org/10.1016/j.jbankfin.2005.05.015

Berger, A. N., Hasan, I., \& Zhou, M. (2009). Bank ownership and efficiency in China: What will happen in the world's largest nation?. Journal of Banking and Finance, 33, 113-130. http://dx.doi.org/10.1016/j.jbankfin.2007.05.016

Bonaccorsi Di Patti, E., \& Hardy, D. (2005). Bank reform and bank efficiency in Pakistan. Journal of Banking and Finance, 29.

Bonin. J. P., Hasan. I., \& Wachtel, P. (2004). Bank performance, efficiency and ownership in transition countries. Journal of Banking \& Finance, 29(1), 31-53. http://dx.doi.org/10.1016/j.jbankfin.2004.06.015

Caprio G., \& Levine R. (2003). Corporate governance of banks: Concepts and international observations. National Bureau of Economic Research (NBER), Working Paper, No. 10158.

Caprio G., Laeven L., \& Levine R. (2007). Ownership and bank valuation. Journal of Financial Intermediation, 16, 584-617. http://dx.doi.org/10.1016/j.jfi.2006.10.003

Charreaux G. (1997). The corporate governance: Corporate Governance Theories and Facts. Paris, Economica, collective work.

Chen S. H., \& Liao C. C. (2011). Are foreign banks more profitable than domestic banks? Home- and host-country effects of banking market structure, governance, and supervision. Journal of Banking and Finance, 35, 819-839. http://dx.doi.org/10.1016/j.jbankfin.2010.11.006

Claessens S., Demirgüç-Kunt A., \& Huizinga H. (2001). How does foreign entry affect the domestic banking market?. Journal of Banking and Finance, 25, 891-911. http://dx.doi.org/10.1016/S0378-4266(00)00102-3

Claessens S., \& Laeven, L. (2004). What drives bank competition? Some international evidence. Journal of Money, Credit, and Banking, 36, 563-583. http://dx.doi.org/10.1353/mcb.2004.0044

Coelli. T. (2003). A Guide to FRONTIER Version 4.1: A Computer Program for Stochastic Frontier Production and Cost Function Estimation. Centre for Efficiency and Productivity Analysis University of New England Armidale, NSW, 2351 Australia, CEPA Working Paper 96/07.

Crespí R., García-Cestona M. A., \& Salas V. (2004). Governance mechanisms in Spanish Banks: Does ownership matter?. Journal of Banking and Finance, 28(10), 2311-2330. http://dx.doi.org/10.1016/j.jbankfin.2003.09.005

Demestz H., \& Villalonga B. (2001). Ownership Structure and Corporate Performance?. Journal of Corporate Finance, 7, 209-233. http://dx.doi.org/10.1016/S0929-1199(01)00020-7

Gary S., \& Gleason E. (1999). Board structure, ownership, and financial distress in banking firms. International Review of Economics and Finance, 8, 281-292.

Griffith J., Fogelberg L., \& Weeks H. (2002). CEO ownership, corporate control and bank performance. Journal of Economics and Finance, 26, 170-183. http://dx.doi.org/10.1007/BF02755984

Jiang C., Yao S., \& Zhang Z. (2009). The effects of governance changes on bank efficiency in China: A stochastic distance function approach. China Economic Review, 20, 717-731. http://dx.doi.org/10.1016/j.chieco.2009.05.005

La Porta R., Lopez-de-Silanes F., \& Shleifer A. (2002). Government ownership of commercial banks. Journal of Finance, 57, 265-301. http://dx.doi.org/10.1111/1540-6261.00422

Laeven L., \& Levine R. (2009). Bank governance, regulation and risk taking. Journal of Financial Economics, 93, 259-275. http://dx.doi.org/10.1016/j.jfineco.2008.09.003

Lang L., \& So R. (2002). Bank ownership structure and economic performance. SSRN Working Paper.

Levine R. (2004). The Corporate governance of banks: A concise discussion of concepts and evidence. The World Bank Policy Research, Working Paper Series No. 3404. 
Lipton M., \& Lorsch J. (1992). A modest proposal for improved corporate governance. Business Lawyer, 48, 59-77.

Macey J. R., \& O'Hara M. (2003). The corporate governance of banks. Economic Policy Review, 9, 91-108.

Mc Connel J., \& Servaes H. (1990). Additional evidence on equity ownership and corporate value. Journal of financial economics, 27.

Nam S. W. (2004). Corporate Governance of Banks: Review of Issues. Working Paper of Asian Development Bank Institute (ADBI).

Pi L., \& Timme S. (1993). Corporate Control and Bank Efficiency. Journal of Banking and Finance, 17, 515-530. http://dx.doi.org/10.1016/0378-4266(93)90050-N

Pinteris G. (2002). Ownership structure, Board characteristics and performance of Argentine Banks. Working Paper, University of Illinois.

Polo A. (2007). Corporate governance of banks: the current state of the debate. MPRA Paper No. 2325.

Prowse S. (1997). Corporate Control in Commercial Banks. Journal of Financial Research, 20, 509-527.

Shleifer A., \& Vishny R. (1997). A Survey of Corporate Governance. The Journal of Finance, 52, 737-783. http://dx.doi.org/10.2307/2329497

Spong K., DeYoung R., \& Sullivan R. J. (1996). What makes a bank efficient? A look at financial characteristics and bank management and ownership structure. Financial Industry Perspectives, Federal Reserve Bank of Kansas City.

Weill L. (2006). Foreign Ownership and technical efficiency of banks in countries in transition: An analysis by the DEA. Economic Review, 5(57), 1093-1108.

Weill L. (2007). Is there a Gap in Bank Efficiency between CEE and Western European Countries?. Comparative Economic Studies, 49, 1-101. http://dx.doi.org/10.1057/palgrave.ces.8100183

\section{Notes}

Note 1. Berle, A. A., \& Means, G. C. (1932). The Modern Corporation and Private Propoperty. New York: Commerce Clearing House.

Note 2. Delorme A. (2002). Stability of the banking systems in emerging markets: a proposal for differentiated prudential regulation. 19th International Workshop on Monetary and Banking Economics, Lyon.

Note 3. Caprio G., \& Levine R. (2002). Corporate Governance of Banks: Concepts and International Observations. Global Corporate Governance Forum Research Network Meeting, 2002.

Note 4. Mikkelson W., \& Ruback R. (1985). An empirical analysis of the interfirm equity investment process. Journal of financial economics, 20, 293-315.

Note 5. Barclay M., \& Hoderness C. (1991). Negociated blocktrades and corporate control. Journal of finance, 46, 861-878.

Note 6. Leightner, J. E., \& Lovell C. A. K. (1998). The Impact of Finance Liberalization on the Performance of Thai Banks. Journal of Economics and Business, 50(2), 115-131.

Note 7. Lensink R., Meesters A., \& Naaborg I. (2006). Bank Efficiency and Foreign Ownership: Does Good Governance Matter? Groningen: University of Groningen.

Note 8. Barth, J. R., Caprio, Jr., \& Levine, R. (2000). Banking Systems around the Globe: Do Regulation and Ownership Affect Performance and Stability? in Prudential regulation and supervision: What works and what doesn't?, Ed ${ }^{\circ}$ Mishkin Frederic, National Bureau of Economic Research.

Note 9. Whidbee D. A. (1997). Board Composition and Control of Shareholder Voting Rights in the Banking Industry. Financial Management, 26(4), 27-41.

Note 10. Linck J., \& Netter J. (2006). The Determinants of Board Structure. University of Georgia Working Paper.

Note 11. Sridharan U., \& Marsinko A. (1997). CEO duality in the paper and forest products industry. Journal of Financial And Strategic Decisions, 10(1).

Note 12. The sample for this study focuses on the following banks: The Amen Bank (AB), The Arab Tunisian 
Bank (ATB), The International Arab Bank of Tunisia (BIAT), the National Agricultural Bank (BNA), Bank of South (BS on May 29, 2006, the South Bank is taking a new name "ATTIJARI BANK."), Banque de Tunisie (BT), the Tunisian Banking (STB), Union Bancaire for Trade of the industry (UBCI), the International Banking Union (IBU)

Note 13. Tunisian-Emirates Bank for Investment (BTEI) is excluded from our sample, since this is a development bank that turned into a universal bank in April 2004.

Note 14. We retain the proposed approach and Lindelly Sealy (1977), that banks are considered a financial institution that uses labor, physical capital and deposits for the production of finished products and services. Consistent with this theoretical way, commercial banks vis-à-vis deposits behave as if they were in front of an input. The inputs correspond to financial capital consists primarily of deposits and borrowed funds in the financial market which are added physical capital and labor. The outputs, however, are measured through the volume of credits and portfolio investments.

Note 15. Clowell R. J., \& Davis E. P. (1992). Output and Productivity in Banking. Scandinavian Journal of Economics, 94, 111-129.

Note 16. Coelli, T., Prasada Rao, D. S., \& Battese G. E. (1998). An Introduction to Efficiency and Productivity Analysis. London: Kluwer Academic Publishers.

Note 17. Barclay M., \& Hoderness C. (1991). Negociated blocktrades and corporate control. Journal of finance, 46, 861-878.

Note 18. Lensink, R., Meesters A., \& Naaborg, I. (2006). Bank Efficiency and Foreign Ownership: Does Good Governance Matter?. Groningen: University of Groningen.

Note 19. Montandrau S. (2006). Activisme des investisseurs institutionnels et performance boursière: les caractéristiques du conseil d'administration qui permettent la confiance. CEROG -IAE d'Aix en Provence Université d'Aix- Marseille III.

Note 20. Klein A. (1998). Firm Performance and Board Committee Structure. Journal of Law and Economics, 41, 275-299.

Note 21. Sridharan U., \& Marsinko A. (1997). CEO duality in the paper and forest products industry. Journal of Financial And Strategic Decisions, 10(1), 1997.

Note 22. Godard L., \& Schatt A. (2000). Should we separate the functions of decision and control?. Paper presented research papers to international AFFI, ESC Paris, June.

Note 23. The size is measured by total assets.

Note 24. Gertner R., \& Kaplan S. (1996). The value-maximising board. Working Paper of University of Chicago and the National Bureau of Economics Research. 